\title{
Penurunan Minat bersekolah di SD Negeri dibandingkan SD Islam: Studi Kasus di Kecamatan Garum Kabupaten Blitar
}

\author{
Riyadus Solihin $^{(1)}$ \& Achmad Ryan Fauzi ${ }^{(2)}$ \\ ${ }^{1,2}$ Universitas Nahdlatul Ulama Blitar \\ 1'ryadssholikin@gmail.com \& 2 achmadryan@unubitar.ac.id
}

\begin{tabular}{l} 
Tersedia Online di \\
\hline http://www.jurnal.unublitar.ac.id/ \\
index.php/briliant \\
\hline Sejarah Artikel \\
\hline Diterima pada 22 Juli 2017 \\
Disetuji pada 24 Juli 2017 \\
Dipublikasikan pada: 2 Agustus \\
2017 Hal 392-401 \\
\hline
\end{tabular}

Kata Kunci:

Penurunan minat, bersekolah, sd negeri, sd islam.

\begin{abstract}
Abstrak: Penelitian ini dilatar belakangi oleh adanya fenomena yang terjadi di Kecamatan Garum Kabupaten Blitar. Dimana ketika memasuki usia sekolah dasar kebanyakan orang tua siswa memilih menyekolahkan anaknya ke Madrasah Ibtidaiyah (MI) atau Sekolah Dasar Islam (SDI). Tujuan penelitian ini adalah untuk mengetahui penyebab penurunan minat untuk bersekolah di Sekolah Dasar Negeri dibandingkan Sekolah Dasar Islam. Penelitian ini merupakan penelitian kulitatif berjenis studi kasus. Hasil penelitian menunjukkan bahwa penurunan minat ini disebabkan karena program pendidikan keagamaan di SDI/MI lebih banyak dan seimbang daripada di SDN. Sementara saat ini masyarakat sangat membutuhkan sekolah yang berbasis keagamaan dengan harapan adanya kesimbangan antara ilmu umum dan agama yang kelak dapat membentuk akhlak anak mereka.
\end{abstract}

Pendidikan merupakan salah satu bidang stategis yang turut menentukan kemajuan suatu bangsa. Hal ini didukung bahwa pendidikan merupakan salah satu dari tiga indikator penentu kemajuan bangsa yang terangkum dalam indek pembangaunan manusia (BPS RI, 2016). Pendidikan menjadi pilar penting dalam mengembangan diri manusia untuk menguasai bidang-bidang yang lain. Sebagai contoh di Jepang, Negara yang pernah porak poranda dan tidak memiliki sumberdaya alam yang memadai namun saat ini bisa menguasai dunia karena mereka memahami bahwa masa depan sangat ditentutan oleh pendidikan dan pembangunan manusianya (Neamtu, 2014). Juga kebijakan European Council, saat ini menerapkan sistem pendidikan yang mengarahakan siswa untuk mendapatkan pengetahuan dan keterampilan dalam menghadapi tantangan ekonomi dan sosial di era globalisasi dunia (Seiça \& Sanches, 2013). Ada Juga Malaysia yang ingin menjadi Negara maju dan kompetitif berbasis riset, maka sistem pendidikannya dikembangkan dengan menekankan pada keberhasilan pembelajaran sains (Veloo, Perumal, \& Vikneswary, 2013).

Pendidikan diartikan sebagai suatu usaha sadar untuk mencapai suatu pengetahuan, sikap dan keterampilan. Pendidikan adalah usaha sadar dan terencana untuk mewujudkan suasana belajar dan proses pembelajaran agar peserta didik secara aktif mengembangkan potensi dirinya untuk memiliki kekuatan spiritual keagamaan, pengendalian diri, kepribadian, kecerdasan, akhlak mulia, serta keterampilan yang diperlukan dirinya, masyarakat, bangsa dan Negara (UU No. 23 Tahun 2003). Pendidikan dalam arti luas adalah transmisi dan transformasi pengetahuan (knowledge), nilai-nilai (values), dan keterampilan- 
keterampilan (skils) yang berlangsung di dalam dan di luar sekolah yang berlangsung seumur hidup (Siswoyo, 2013:109).

Pendidikan bukan hanya sekedar membuat peserta didik pandai menghapal tetapi yang lebih penting ialah menjadikannya sebagai manusia, atau dalam istilah Driyakarya, pendidikan merupakan proses memanusiakan manusia (Pramudia, 2006:31). Pendidikan harus peduli terhadap upaya untuk mencegah perilaku kekerasan atau perilaku tidak terpuji lainnya secara dini melalui program pendidikan, agar budaya damai, sikap toleransi, empati, dan sebagainya, dapat ditanamkan kepada peserta didik (Wahyu, 2011). Untuk itu, pendidikan harus menyediakan dasar keberlanjutan hidup bangsa dalam semua aspek kehidupan nasional yang mencerminkan karakter bangsa saat ini (Zainuddin, 2016).

Pendidikan adalah untuk memberikan pengetahuan dan keterampilan yang dibutuhkan siswa sebagai bekal kehidupan mereka di masyarakat modern dan menjadikan pengetahuan mereka berguna untuk kelayakan kerja sama ini, dan masa depan (Serafín, Dostál \& Havelka, 2014). Pengalaman bersekolah (Pendidikan) dapat mengembangkan keterampilan akademik dan komptensi serta merubah hidup siswa. (Burchinal \& Peisner-Feinberg, 2002; Carvalho, Martins, Santana \& Feliciano, 2014).

Meninjau pada tujuan pendidikan nasional, arah pendidikan di Indonesia adalah untuk mengembangakan kompetensi pada diri siswa. Pendidikan nasional berfungsi mengembangkan dan membentuk watak serta peradaban bangsa yang bermartabat dalam rangka mencerdaskan kehidupan bangsa (UU RI nomor 20 tahun 2003). Untuk mengembangkan dan membentuk watak dan peradaban bangsa yang bermartabat, pendidikan berfungsi mengembangkan segenap potensi peserta didik menjadi manusia yang beriman dan bertaqwa kepada Tuhan Yang Maha Esa, berakhlak mulia, sehat, berilmu, cakap, kreatif, mandiri, dan menjadi warganegara yang demokratis serta bertanggungjawab (UU RI nomor 20 tahun 2003).

Di Indonesia pendidikan terbagi dalam empat jenjang, yaitu prasekolah (pendidikan anak usia dini), pendidikan dasar, pendidikan menengah, dan pendidikan tinggi. Secara umum pendidikan diatur oleh Kementerian Pendidikan dan Kebudayaan dengan Sekolah Dasar Negeri untuk tingkat dasar. Di sisi lain juga terdapat peran dari Kementerian Agama yang turut serta mengembangkan pendidikan dengan Madrasah Ibtidiyah di tingkat dasar.

Dewasa ini terjadi suatu perpindahan paradigma di masyarakat khususnya pada jenjang pendidikan dasar. Dimana saat ini masyarakat lebih memercayakan pendidikan anak-anaknya pada sekolah-sekolah yang memiliki label keagaaman seperti Sekolah Dasar Islam (SDI) dan Masdrasah Ibtidaiyah (MI). Hal ini berdampak pada meningkatknya jumlah siswa SDI dan MI dibarengai dengan menurunnya jumlah siswa SD negeri. Dengan demikian saat ini SDI dan MI lebih dimanati oleh masyarakat daripada SD negeri. Terjadi suatu kontradiksi dimana dulu SD negeri lebih diminati dari pada SDI/MI.

Hal tersebut terjadi hampir di beberapa kawasan salah satunya di Kecamatan Garum Kabupaten Blitar. Wilayah Kecamatan Garum, terdapat beberapa SD Negeri yang letaknya berdekatan dengan SDI atau MI dan jumlah siswanya pun lebih banyak SDI atau MI. Masyarakat disekitar tempat tersebut ketika ditawakan secara bersamaan memutuskan untuk menyekolahkan anaknya di SDI atau MI. Pada perhitungan awal Sekolah Dasar Negeri di Kecamatan

393 BRILIANT: Jurnal Riset dan Konseptual Volume 2 Nomor 3, Agustus 2017 
Garum pada tahun ajaran 2016/2017 mengalami penurunan sebesar 3,7\% dalam jumlah siswa. Sedangkan Sekolah Dasar yang menggunakan sistem Full Day (SDI/MI) wilayah Garum mengalami peningkatan sebesar 10,4 \% jumlah siswa (Dapodik, 2016).

Terlihat jelas minat yang tinggi kepada SDI /MI daripada SD Negeri. Lalu apa yang sebenarnya terjadi? Mengapa masyarakat lebih berminat pada SDI dan MI serta meninggalkan SD Negeri? Apakah ada hal yang salah pada system pendidikan dan pembelajaran di SD Negeri? Ataukah ada keunggulan dan kompetensi lebih yang dimiliki oleh SDI dan MI yang memberikan pembeda.

\section{METODE}

Penelitian ini menggunakan pendekatakan penelitian kualitatif. Penelitian kualitatif merupakan metode penelitian yang berlandaskan pada filsafat postpositivisme, digunakan untuk meneliti pada kondisi obyek yang alamiah, dimana peneliti adalah sebagai instrumen kunci, pengambilan sampel sumber data dilakukan secara purposive dan snowball, teknik pengumpulan trianggulasi, analisis data bersifat induktif kualitatif, dan hasil penelitian kualitatif lebih menekankan makna dari generalisasi (Sugiyono, 2015). Proses penelitian kualitatif ini melibatkan upaya-upaya penting, seperti mengajukan pertanyaanpertanyaan dan prsedur-prosedur, mengumpulkan data yang spesifik dari para partisipan, menganalisis data secara induktif mulai dari tema-tema yang khusus ke tema-tema umum, dan menafsirkan makna data (Creswel, 2014).

Adapun jenis dari penelitian kualitatif yang digunakan adalah studi kasus. Studi kasus merupakan suatu jenis pendekatan penelitian kualitatif yang memungkinkan peneliti untuk menganalisis lebih dalam suatu peristiwa (kasus) menggunakan berbagai macam sumber data (Baxter \& Jack, 2008). Studi Kasus juga memperbolehkan peneliti untuk menganalisis kasus tentang individu atau organisasi, intervensi, hubungan relasi, dan program (Yin, 2003).

Dalam studi kasus ini peneliti memiliki peranan vital dalam menafsirkan dan mengumpulkan data-data penelitian. Adapun data-data penelitian diperoleh melalui observasi dan wawancara. Observasi dilakukan di sekolah - sekolah yang menjadi obyek penelitian, yaitu SDN Tawangsari 01 Kecamatan Garum dan SDI Maarif Garum. Sedangkan wawancara dilakukan kepada informan, yaitu (1) Kepala SDN Tawangsari 01, (2) Perwakilan Wali Murid SDN Tawangsari 01, (3) Kepala SDI Ma'arif Garum dan (4) Perwakilan Wali Murid SDI Ma'arif Garum.

Untuk membuktikan validitas data yang diperoleh, peneliti kemudian melakukan trianggulasi. Trianggulasi adalah suatu pendekatan analisis data yang mensintesis data dari berbagai sumber (Bachri, 2010:55). Trianggulasi yang dilakukan meliputi trianggulasi metode dan trianggulasi informan. Trianggulasi metode dilakukan dengan melakukan pengumpulan data melalui teknik dokumentasi. Melalui teknik ini dilakukan penghimpunan dan pengumpulan data dari dokumen yang ada (Sukmadinata, 2015:221). Dalam hal ini adalah Data Pokok Pendidikan (Dapodik). Sedangkan trianggulasi informan dilakukan dengan cara mewawancarai informan diluar informan utama namun terlibat dalam kasus ini, yaitu (1) Guru SDN Tawangsari 01 Garum, (2) Guru SDI Ma'arif Garum dan (3) Tokoh Masyarakat Kelurahan Tawangsari.

Data yang diperoleh kemudian dianalisis secara mendalam. Analisis dilakukan untuk melakukan interpretasi dan penafsiran terhadap data-data 
penelitian yang telah diperolah. Analisis dilakukan dengan mengadopsi langkah yang dikembangkan oleh Miles, Hubberman \& Saldana (2014), yaitu (1) Reduksi data, (2) Penyajian Data, dan (1) Penarikan Kesimpulan. Lebih lanjut, dalam reduksi data dilakukan seleksi dan pemilahan data-data. Data dipilah mana yang diperlukan dan mana yang tidak diperlukan. Kemudian data yang telah dipilah dirangkai sedemikian rupa sehingga mudah digeneralisasi dan diverivikasi. Akhirnya data yang telah dirangkai digeneralisasi dan diverivikasi untuk menarik suatu kesimpulan.

\section{HASIL}

Dalam penelitian ini peneliti mengambil obyek studi SDN dan SDI di wilayah Kecamatan Garum. Secara khusus dipilih SDN Tawangsari 1 dan SDI Ma'arif Garum yang terletak di Kelurahan Tawangsari Kecamatan Garum. SDN Tawangsari 01 Garum merupakan salah satu SDN yang mengalai dampak penurunan jumlah setiap tahunnya. Sedangkan SDI Ma'arif Garum merupakan SD berbasis pendidikan Islam yang semakin naik daun dengan adanya fenomena penurunan minat besekolah di SD Negeri. Dalam penelitian ini penulis melakukan observasi dan wawancara terkait dengan sarana-prasarana sekolah, tenaga kependidikan, pembelajaran, program sekolah yang dikaitkan dengan tanggapan wali murid.

\section{Sarana-prasarana sekolah}

Dari aspek sarana-prasarana baik SDN tawangsari 01 maupun SDI Ma'arif Garum memiliki sarana prasarana yang memadai untuk melaksanakan kegiatan belajar mengajar. Walaupun untuk beberapa fasilitas masih belum ada dan masih dalam proses pengadaan. Pun demikian lingkungan sekolah sudah ditata dan diatur sedemikian rupa sehingga terciptalah sekolah yang nyaman dan aman. Untuk ruang kelas, keduanya juga telah memenuhi dan mencukupi untuk melakukan kegiatan pembelajaran dengan kelas parallel.

Fasilitas penunjang kegiatan pembelajran beberapa diantaranya juga telah memenuhi. Di SDN Tawangsari 01 terdapat aula, termpat ibadah, toilet, tempat olahraga. Sedangkan di SDI Ma'arif Garum terdapat tempat ibadah, toilet, tempat olahraga, kantin, aula, laboratorium, perpustakaan.

\section{Tenaga Kependidikan}

Dari aspek tenaga kependidikan, SDN tawangsari 1 Garum telah memnuhi rasio 1:20 (satu guru untuk dua puluh siswa) sehingga bisa dikatakan sudah mencapai standar. Namun demikian SD ini masih memiliki kekurangan yaitu belum memiliki guru agama tetap. Guru agama yang dimiliki oleh SDN Tawangsari 1 sifatnya masih rangkap dengan SDN lain.

Sedangkan untuk SDI Ma'arif garum juga sudah memenuhi rasio minimal 1:20 (satu guru untuk dua puluh siswa). Sehingga bisa dikatakan sudah mencapai standar. Yang menjadi keunggulan di SDI ma'arif garum, adalah masing-masing guru memiliki keterampilan mengaji yang baik. Hal ini menjadi syarat mutlak bagi mereka yang mengajar di SDI ini. Selain itu SDI ini juga telah memiliki guru-guru keagamaan yang mumpuni sehingga untuk pendidikan keagamaan telah memiliki ahlinya tanpa mengambil dari luar sekolah. 


\section{Pembelajaran}

SDN Tawangsari 1 Garum merupakan SDN unggulan di wilayah kecamatan Garum, seringkali sistem pembelajaran yang diterapkan di SDN ini dirujuk oleh SDN lain yang berada di wilayah Kecamatan Garum. SDN ini sudah menerapkan Kurikulum 2013 (K13) dengan berbasis keilmuan umum. Sedangkan SDI Ma'arif Garum, sama halnya dengan SDN Tawangsari Garum telah menerapkan Kurikulum 2013 (K13). Sistem pembelajaran yang diterapkan di SDI ini merupakan perpaduan antara pendidikan umum dan pendidikan keagamaan. Sehingga dalam penerapan K13 tidak hanya berbasis pada keilmuan umum akan tetapi juga berbasis pada keilmuan agama.

\section{Program Sekolah}

Kedua sekolah ini merupakan sekolah yang telah terakrediatasi. Sehingga dalam melakukan administrasi dan pengelolaan program sekolah telah dilakukan dengan baik. Akan tetapi kedua SD ini memiliki program berbeda untuk meningkatkan partisipasi masyarakat dalam pendidikan dan pembelajaran di sekolah masing-masing.

Di SDN Tawangsari menawarkan program pembelajaran reguler berbasis keilmuan umum dengan tambahan jam pendidikan keagamaan. Tambahan jam pendidikan keagamaan ini merupakan program baru yang masih beberapa tahun ini berjalan. Sehingga penerapannya masih belum berjalan dengan maskimal karena masih bersifat seperti ekstra dan tenaga pengajar bukan tenaga tetap. Namun demikian program ini dapat menarik minat wali murid untuk menyekolahkan anaknya di SDN ini. Sehingga SDN ini masih mendapat cukup siswa untuk pelaksanaan KBM yang terstandar.

Di SDI maarif garum menawarkan program pemebelajaran full day berbasis keilmuan umum dan agama yang diajarkan secara seimbang. Dengan harapan lulusan SDI ini dapat menguasai ilmu umum dan ilmu agama. Salah satu yang menjadi unggulan di SDI ini sesuai namanya terdapat pendidikan keagamaan secara intensif. Hal inilah yang menjadi pedoman pelakasanakan KBM di SDI. Pendidikan keagamaan ini setara dengan pendidikan umum dan sifatnya bukan sekedar ekstra. Dengan program ini, banyak wali murid yang tertarik untuk menyekolahkan anak-anaknya disini. Terlebih program ini mengakomodir kebutuhan wali murid dewasa ini dalam pemenuhan pendidikan keagamaan bagi anak-anaknya. Dengan menyekolahkan anaknya di SDI wali murid merasa mendapat dua kuntungan (ilmu umum dan ilmu agama bagi anaknya) tanpa harus mencari lembaga pendidikan keagamaan di luar sekolah.

\section{PEMBAHASAN}

Dari hasil penelitian tersebut dapat dilihat bahwa kedua sekolah tersebut secara umum sama. Keduanya telah terakreditasi dilengkapai dengan fasilitas penunjang yang hampir sama. Dari segi pembelajaran pun keduanya juga telah menerapkan kurikulum 2013. namun dari segi program, keduanya berbeda. SDN Tawangsari 1 menerapkan program pembelajaran berbasis umum dengan tambahan pendidikan keagamaan. Sedangkan SDI Ma'arif Garum menerapkan program pembelajaran full day berbasis keseimbangan ilmu umum dan ilmu agama khusunya agama Islam.

396 BRILIANT: Jurnal Riset dan Konseptual Volume 2 Nomor 3, Agustus 2017 
Dari hal tersebut dapat diketahui bahwa Sekolah Dasar Islam (SDI) memiliki daya tarik yang lebih kuat dari pada Sekolah Dasar Negeri (SDN) bukan sepenuhnya dikarenakan fasilitas yang ditawarkan akan tetapi perbedaan program pendidikan yang diterapkan. SDI menerapkan program pendidikan dengan memperhatikan kesimbangan anatara ilmu umum dan ilmu agama. Bahkan kecenderungannya beberapa SDI menerapkan program pendididkan full day yang mana tambahan jam dilakukan untuk memperkuat ilmu keagamaan. Full day school sendiri merupakan satu istilah dari proses pembelajaran yang dilaksanakan secara penuh, aktifitas anak lebih banyak dilakukan di sekolah dari pada di rumah (Setiyarini, Joyoatmojo \& Sunardi, 2014).

Disisi lain keberadaan pendidikan tersebut saat ini sangat dibutuhkan oleh masyarakat. Kesadaran masyarakat akan pentingnya pendidikan agama untuk membentuk karakter anak semakin tinggi dewasa ini. Mereka sangat berharap anak yang disekolahkan di SDI/MI memiliki pengetahuan yang seimbang antara agama dan umum. Mereka memilih SDI dengan melihat isi dari pelajaran di SDI yang tidak hanya berdasar materi tetapi juga karakter yang nyata. Oleh karena itu, konten pendidikan yang dipelajari bukan hanya masalah tapi juga sikap (Suwarti \& Zainuddin, 2017). Akhirnya akan terbentuk anak yang pinter juga berkarakter (pinter tur beneh).

Pendidikan karakter di SDI terasa lebih efektif karena karakter yang terbentuk disesuaikan dengan norma-norma keagamaan yang dewasa ini mulai ditinggalkan. Bila merujuk kepada ciri kehidupan manusia pada era 2000 (era globalisasi) ini ditandai dengan kehidupan yang serba keras, kehidupan yang penuh tantangan dan persaingan (kompetitif) yang ketat disegala lini kehidupan, perpacuan kehidupan kebendaan (materi) yang berorientasi untuk mendapatkan uang sebanyak-banyaknya, kehidupan menjadi bersifat individualisme dengan melemahnya kepedulian sosial, terjadinya dekadensi moral (kemerosotan akhlak) dan masalah-maslaah penyakit hati manusia lainnya (Nasution, 2013). Kemudian lebih jauh lagi dapat kita amati, dewasa ini para pemuda dan pemudi kita dalam berprilaku lebih banyak meniru-niru yang datang dari Barat, seakan-akan yang mereka lihat dan tonton dari Barat itu patut dicontoh dan diikuti agar jangan ketinggalan zaman (Ansori, 1992). Sehubungan dengan problema tersebutlah maka pendidikan Islam mendapat prioritas utama untuk dibina dan dikembangkan baik melalui pendidikan formal (Nasution, 2013).

Pendidikan di SDI/MI sendiri jika ditelaah lebih lanjut memasukkan sistem pembelajaran bergaya pesantren. Dapat dilihat dari keilmuan agama dan kurikulum kagamaan yang dijalankan memiliki kemiripan dengan yang ada di pondok pesantren. Misalnya pelajaran tentang keaswajaan, hadist, fiqih, tasawuf, bahasa arab, dan juga adab. Dalam sejarah perjalanannya, pesantren telah berhasil melakukan upaya-upaya kontekstualisasi ajaran Islam dengan budaya lokal (Solichin, 2012). Pesantren secara umum telah berperan dalam perdamaian, menjaga stabilitas dan mengakomodasi hubungan yang harmonis antara tradisi lokal dan nilai-nilai dari luar (Sholeh, 2007), Pada tataran normatif dan empiris pesantren memiliki konstribusi besar untuk memberikan pandangan, sikap serta alternative untuk meminimalisir berkembangnya gerakan radikal agama, seperti terorisme diantaranya dengan menerapkan pendidikan peace building sebagai upaya antisipasif di kalangan masyarakat pesantren dan sekitarnya (Fitriani, 2015).

397 BRILIANT: Jurnal Riset dan Konseptual Volume 2 Nomor 3, Agustus 2017 
Pesantren adalah Lembaga pendidikan khusus yang berakar pada sejarah pendidikan yang panjang di Indonesia. Pesantren sangat peduli dalam pemberdayaan masyarakat khususnya di bidang pendidikan (Lawson, 2010; Scott, 2011). Setelah proses yang panjang, pesantren akhirnya diberi tanggung jawab dan kepercayaan oleh masyarakat sebagai pusat pendidikan Islam. Selanjutnya, ketika seorang anggota masyarakat memiliki masalah terkait Pendidikan dan agama, pesantren menjadi rujukan pertama dan utama. Ini menunjukkan betapa berharganya pesantren sebagai bagian instrumental masyarakat Indonesia. Sebelum Indonesia merdeka, pesantren sudah ada. Pesantren beradaptasi dalam mendukung pengajaran dan pembelajaran hal ini menunjukkan bahwa institusi ini menerapkan teknologi informasi dan komunikasi sebagai bagian dari pengajarannya (Wekke, 2015; Wekke dan Hamid, 2013). Maka dari itu, setiap berdirinya SDI pasti ada tokoh-tokoh kyai atau lulusan pondok pesantren yang berperan aktif dibelakangnya.

Hal demikian tidak terjadi di Sekolah Dasar Negeri, SD Negeri memiliki program pendidikan yang berbeda dengan SDI. Sebagai sekolah dasar umum, SDN menitik beratkan pendidikannya pada ilmu-ilmu umum. Disadari atau tidak pendidikan keagamaan menjadi wajib namun tidak terlalu diperhatikan.

Sekolah dasar negeri merupakan sekolah dasar umum yang dikelola oleh peerintah. Program-program pendidikan di SD Negeri berorientasi untuk kepentingan masyarakat secara umum. Namun demikian dalam pendidikan agama, kurang dititik beratkan. Hal ini kemudian terjadilah penurunan minat masyarakat. Di SD Negeri masyarakat kirang praktis dalam pendidikan keagamaan.

Oleh karena itu, sebagai upaya kembali menjaring murid SD Negeri mulai menambahkan jam pendidikan keagamaan. Hal ini patut diapresiasi. Namun, perlu diperhatikan juga dalam distribusi dan pengelolaan waktunya mengingat pada hakikatnya SD Negeri berbeda dengan SD Islam yang memang berbasis umum dan keagamaan

Inilah perbedaan SDN dengan SDI yang nampak sekarang ini. Sehingga model pendidikan SDN sekarang ini kurang sesuai dengan apa yang dibutuhkan oleh masyarakat.

Maka benar apa yang dikatakan oleh Serafín, Dostál \& Havelka (2014) bahawa pendidikan adalah untuk memberikan pengetahuan dan keterampilan yang dibutuhkan siswa sebagai bekal kehidupan mereka di masyarakat modern dan menjadikan pengetahuan mereka berguna untuk kelayakan kerja sama ini, dan masa depan. Serta Zainuddin (2016) bahwa Pendidikan harus menyediakan dasar keberlanjutan hidup bangsa dalam semua aspek kehidupan nasional yang mencerminkan karakter bangsa saat ini.

Seiring dengan perubahan jaman dan pemikiran masyarakat saat ini, maka sekolah dasar yang tidak mau berinovasi dan merubah model pendidikannya pasti akan ditinggalkan oleh masyarakat. Masyarakat akan memilih menyekolahkan anaknya pada sekolah yang memang memberikan harapan akan kebutuhannya. Walaupun letak sekolah tersebut terletak jauh dari tempat tinggal.

\section{KESIMPULAN}

Terjadinya penurunan minat masyarakat untuk menyekolahkan anaknya di Sekolah Dasar Negeri disebabkan oleh penerapan pendidikan keagamaan yang 
dianggap kurang oleh masyarakat. Sedangkan saat ini masyarakat sangat membutuhkan pendidikan keagaamaan yang lebih banyak porsinya bagi anakanak mereka. Seiiring kebutuhan tersebut hadirlah SDI/MI tengah masyarakat dengan tawaran jam pendidikan keagamaan yang lebih banyak dan seimbang. Hal ini kemudian yang memberikan minat lebih bagi masyarakat untuk menyekolahkan anaknya pada SDI/MI. Sehingga kebutuhan mereka akan pendidikan yang seimbang antara ilmu umum dan agama dapat terpenuhi tanpa harus repot mencari lembaga pendidikan keagaaman diluar lembaga pendidikan umum (SDN).

\section{SARAN}

Sebaiknya Sekolah Dasar Negeri dapat menerapkan tambahan jam pendidikan keagamaan kepada siswanya. Secara teknis penearapan tersebut dapat dilakukan dengan aplikasi nilai pendidikan keagamaan, misalnya melakukan pengajian (bina iman bagi non muslim) setiap sebelum pelajaran hari itu dimulai, melakukan sholat dhuha, dan sebelum pulang sekolah melaksanakan sholat dzuhur berjamaah. Selain itu juga bisa diterapkan ekstrakurilkuler berbasis keagamaan seperti qiroah, samroh, dll. Serta sekolah bisa mengadakan lombalomba internal atau eksternal berbasis keagamaan seperti lomba adzan, lomba tartil, lomba sholawat dan lain-lain. Sedangkan bagi SDI bisa berbagi ilmu dalam pendidikan keagamaan dan melakukan kerjasama dalam penjaringan siswa baru sehingga baik SDN maupun SDI dapat tetap menjalankan aktivitas belajar dan mengajar. Sebagai upaya bersama mencerdaskan kehidupan bangsa.

\section{DAFTAR RUJUKAN}

Ansori, Khairil. 1992. Sebuah Alternatif Menghadapi Arus Globalisasi

Bachri. B.S. 2010. Meyakinkan Validitas Data melalui Trianggulasi pada Penelitian Kualitatif. Jurnal Teknologi Pendidikan, 10(1): 46-62.

Badan Pusat Statistik Republik Indonesia. 2016. Index Pembangunan Manusia. (Online), (https://www.bps.go.id/Subjek/view/id/26), diakses 15 Februari 2015.

Baxter, Pamela. \& Jack, Susan. 2008. Qualitative Case Study Methodology: Study Design and Implementation for Novice Researchers. The Qualitative Report. (Online), 13(4): 544-559. (http://www.nova.edu/ssss/QR/QR134/baxter.pdf), diakses 16 Juli 2017.

Burchinal, M. R. \& Peisner-Feinberg, E. (2002). Development of Academic Skills from Preschool Through Second Grade: Family and Classroom Predictors of Developmental Trajectories. Journal School Psychology, $40(5), 415-436$.

Carvalho, Carolina., Martins, Dulce., Santana, Lidia E. Feliciano, Luis. 2014. Teacher Feedback: Educational Guidance in Different School Contexts. Procedia - Social and Behavioral Sciences, (Online) 159: 219 - 223. (http://www.sciencedirect.com), diakses 10 Februari 2017.

Creswell. John W. 2014. Research Design: Pendekatan Kualitatif, Kuantitatif dan Mixed. terj. Achmad Fawaid. Yogyakarta: Pustaka Pelajar.

Dapodik. 2016. Data Pokok Pendidikan Tahun Ajaran 2016/2017 Jenjang SD di Kecamatan Garum. (Online), (http://dapo.dikdasmen.kemdikbud.go.id/), diakses 25 Januari 2017.

399 BRILIANT: Jurnal Riset dan Konseptual Volume 2 Nomor 3, Agustus 2017 
Fitriani, Laily. 2015. Pendidikan Peace Building di Pesantren: Sebuah Upaya Mencegah Radikalisasi. Ulul Albab. 16(1): 117-130.

Lawson, D. R. (2010). An assessment of Arabic transliteration systems. Technical Services Quarterly, 27 (2), 164-177.

Miles, M.B., Huberman, A.M., \& Saldana, J. 2014. Qualitative Data Analysis: A Methods Sourcebook. Third Edition. SAGE Publication Asia-Pacific Pte. Ltd. Singapore.

Nasution, Sahadir. 2013. Pendidikan Non Formal Kaitannya dengan Pembinaan Remaja. Forum Paedagogik. 5(1): 109-124.

Neamtu, Daniela Mihaela. 2015. Education, the economic development pillar. Procedia - Social and Behavioral Sciences. (Online), 180:413 - 420. (http://www.sciencedirect.com/science/article/pii/S1877042815014846), diakses 10 Februari 2017.

Pramudia. Joni Rahmat. 2006. Orientasi Baru Pendidikan: Perlunya Reorientasi Posisi Pendidik dan Peserta Didik. Jurnal Pendidikan Luar Sekolah, (Online), 3 (1): 29-38, (http://file.upi.edu/Direktori/FIP/JUR._PEND. LUAR_SEKOLAH/197106141998031-JONI_RAHMAT_PRAMUDIA /JURNAL-ORIENTASI_BARU_PENDIDIKAN.pdf), diakses tanggal 27 Oktober 2016.

Scott, D. G. (2011). The spiritual as critical and political. International Journal of Children's Spirituality, 16 (4), 293-299.

Seica, Aline., \& Sanches, Maria de F C. 2014. School Equity: The Students' Perspectives in Diverse School Contexts. Procedia - Social and Behavioral Sciences, (Online) 116: 2015 - 2022. (http://www.sciencedirect.com/science/article/pii/S1877042814005308), diakses 10 Februari 2017.

Serafín, Čestmír., Dostál, Jiří., \& Havelka, Martin. 2015. Inquiry-Based Instruction in The Context of Constructivism. Procedia - Social and Behavioral Sciences, (Online), 186: 592 - 599, (http://www.sciencedirect.com/science/article/pii/S1877042815023101), diakses 18 Januari 2017.

Setyarini, Ida Nurhayati., Joyoatmojo, Sutarno., \& Sunardi. 2014. Penerapan Sistem Pembelajaran "Fun \& Full Day School" untuk Meningkatkan Religiusitas Peserta Didik di SDIT Al Islam Kudus. Jurnal Teknologi Pendidikan dan Pembelajaran. (Online), 2 (2): 231-244, (http://jurnal.fkip.uns.ac.id), diakses 21 Juli 2017.

Siswoyo, Dwi. 2013. Pandangan Bungkarno tentang Panacasila dan Pendidikan. Cakrawala Pendidikan, (Online), 32 (1): 103-115, (http://staff.uny.ac.id /sites/default/files/penelitian/Dr.\%20Dwi\%20Siswoyo,\%20M.Hum./artik el\%20cakrawala.pdf), diakses 23 Juli 2016.

Solichin, Mohammad Muchlis. 2012. Rekonstruksi Pendidikan Pesantren sebagai Character Building menghadapi Tantangan Kehidupan Modern. Karsa. 20(1): 58-74.

Sugiyono. 2015. Metode Penelitian Pendidikan: Penelitian Kuantitatif, Kualitatif dan $R \& D$. Bandung: Alfabeta.

Sukmadinata, Nana Syaodih. 2015. Metode Penelitian Pendidikan. Bandung: Remaja Rosdakarya.

400 BRILIANT: Jurnal Riset dan Konseptual Volume 2 Nomor 3, Agustus 2017 
Suwarti \& Zainuddin, HM. 2017. Social Studies Learning through Cooperative Script Aplication: Development Strategy of Coorperative and Opinion Appreciation Character for Elementary School Students. Journal Of Development Research. (Online), 1(1): 8-14. (http://journal.unublitar.ac.id/jdr), diakses 17 Juli 2017.

Undang-undang RI No. 20 tahun 2003 tentang Sistem Pendidikan Nasional. Sekertariat Negera Republik Indonesia. (Online), (www.setneg.go.id), diakses 11 Juli 2016.

Veloo, Arsaythamby., Perumal, Selvan., \& Vikneswary, R. 2013. Inquiry-based instruction, students' attitudes and teachers' support towards science achievement in rural primary schools. Procedia - Social and Behavioral Sciences, (Online), 93: 65-69, (http://www.sciencedirect.com/science/ article/pii/S1877042813032564), diakses 18 Januari 2017.

Wahyu. 2011. Masalah dan Usaha Membangun Karakter Bangsa. Komunitas, (Online), 3 (2): 138-149, (http://journal.unnes.ac.id /nju/index.php/ komunitas/article/2310/2363), diakses tanggal 23 Juli 2016.

Wekke, I. S. \& Hamid, S. 2013. Technology on Language Teaching and Learning: A Research on Indonesian Pesantren. Procedia - Social and Behavioral Sciences, 83, 585-589.

Wekke, Ismail Suardi. 2015. Arabic Teaching and Learning: A Model From Indonesian Muslim Minority. Procedia - Social and Behavioral Sciences. (Online), 191: 286 - 290. (www.sciencedirect.com), diakses 19 Juli 2017.

Yin, R. K. 2003. Case Study Research: Design and methods. 3rd ed. Thousand Oaks, CA: Sage Publishing.

Zainuddin. 2016. Designing Scientific Learning Model Application in Low-grade of Primary Schools Based on the 2013 Curiculum in East Java, Indonesia. Journal of Social Science (COES\&RJ-JSS), (Online), 5 (3): 229-237,(http://www.centreofexcellence.net/J/JSS/Vol5/No3/JSSarticle3, 5_3_pp229-237.pdf), diakses tanggal 14 September 2016. 